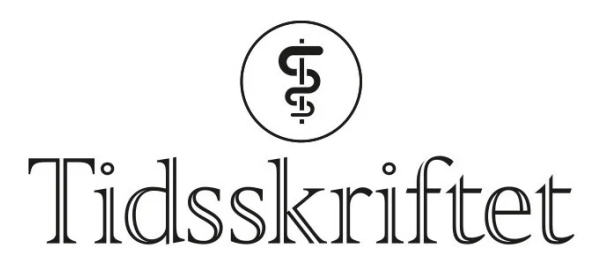

DEN NORSKE LEGEFORENING

\title{
Magnetstyrt ablasjonsbehandling av hjerterytmeforstyrrelser
}

OVERSIKTSARTIKKEL

\section{JIAN CHEN}

Email: jian.chen@med.uib.no

\section{PER IVAR HOFF}

Haukeland universitetssykehus 5021 Bergen

\section{EIVIND SOLHEIM}

Institutt for indremedisin Universitetet i Bergen

\section{PETER SCHUSTER}

\section{MORTEN KRISTIAN OFF}

Hjerteavdelingen

Haukeland universitetssykehus

\section{OLE-JØRGEN OHM}

Institutt for indremedisin Universitetet i Bergen

\section{BAKGRUNN.}

De første rapportene om radiofrekvensablasjon av supraventrikulær takykardi med magnetisk navigasjon ble publisert i 2004. Senere har metoden vært anvendt ved de fleste takyarytmier. I denne artikkelen gir vi en oversikt over den, med spesiell vekt på anvendeligheten av et nytt fjernstyrt magnetisk navigasjonssystem.

MATERIALE OG METODE.

Artikkelen er basert på litteratur funnet ved et ikke-systematisk søk i PubMed og egne vitenskapelige studier. 
Det magnetiske navigasjonssystemet består av to ytre elektromagneter plassert på hver side av pasienten. Disse styrer et ablasjonskateter med en liten magnet i enden til målområdet i hjertet med bedre presisjon enn det som kan oppnås ved manuelt styrte katetre. Det tar ikke lang tid å lære å bruke utstyret, men prosedyretiden er fortsatt lang, særlig gjelder det hos pasienter med atrieflimmer. Den største fordelen er en betydelig reduksjon i strålebelastningen på pasient og operatør, i enkelte tilfeller på mer enn $50 \%$, og tilsvarende mindre fysisk belastning for operatøren. Forekomsten av prosedyrerelaterte komplikasjoner synes å være lavere enn ved bruk av manuelt styrte katetre. Det foregår en kontinuerlig utvikling av ablasjonskatetre og av metoder som kan forenkle kartleggingsprosedyrene og $\emptyset$ ke behandlingseffektiviteten. Basiskostnadene ved etablering av et magnetlaboratorium er tre ganger så høye som kostnadene ved et konvensjonelt elektrofysiologisk laboratorium.

\section{FORTOLKNING.}

Det nye magnetiske navigasjonssystemet har vist seg anvendelig ved ablasjon av et bredt spekter av arytmier, men er fortsatt en metode under utvikling.

Helt siden 1987 har det hos mange pasienter vært mulig å behandle takykardier med kateterablasjon der elektrisk energi leveres via katetre til hjertet. Den teknologiske utviklingen av katetre og tredimensjonale elektroanatomiske registreringssystemer har gitt $ø \mathrm{kt}$ forståelse for mekanismene ved hjertearytmier og dermed muligheter for kurativ behandling av mer kompliserte - i enkelte tilfeller livstruende - arytmier med radiofrekvensablasjon.

Ablasjonsteknikk krever nøyaktig kateterlokalisering og stabil vevskontakt. Hittil har kateterplasseringen vært foretatt manuelt under veiledning av røntgengjennomlysning. Hensikten med denne presentasjonen er å omtale en ny metode der man anvender et fjernstyrt navigasjonssystem i behandlingen av forskjellige takyarytmier. Oversikten er basert på tilgjengelig litteratur og egne erfaringer.

\section{Materiale og metode}

Grunnlaget for artikkelen er et ikke-systematisk litteratursøk i PubMed om kateterablasjonsbehandling av hjertearytmier og egen forskning innen fagfeltet over de siste 20 år.

\section{Navigasjonssystemet, kateterføring og ablasjonsmetode}

Det eneste tilgjengelige magnetiske navigasjonssystem (NIOBE Stereotaxis Inc., St. Louis, MO) for styring av intrakardiale katetre består av to permanente magneter som plasseres på hver side av et gjennomlysningsbord med tilhørende røntgenutstyr. Magnetene danner et lavintensitets magnetfelt på o,o8 tesla inne i pasientens bryst (fig 1a). I dag finnes det kun ett fleksibelt magnetkateter som er fullt integrert med navigasjonssystemet (NaviStar RMT, Biosense Webster, USA) til elektrisk kartlegging og ablasjon. Det har en $4 \mathrm{~mm}$ eller $8 \mathrm{~mm}$ stor elektrode med en liten permanent magnet i enden. I tillegg er det festet to elektroder som registrerer elektriske hjertesignaler til kateteret samt tre innebygde magneter. 

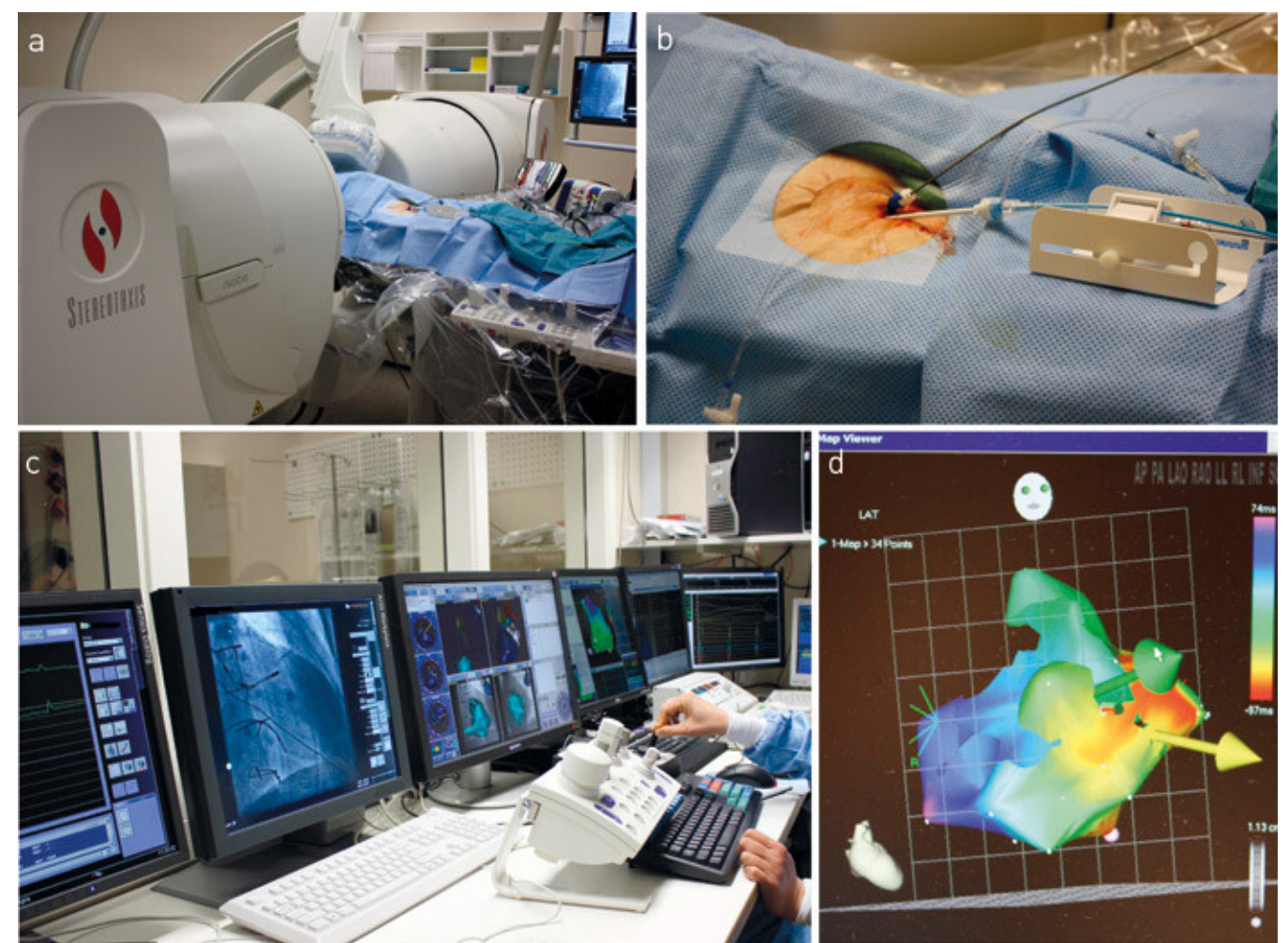

Figur $1 \mathrm{a}$ ) To store magneter (Stereotaxis) danner et felt gjennom pasientens brystkasse.

Røntgengjennomlysning (C-bue) er plassert mellom magnetene. b) Nærbilde av høyre lyskeregion. Magnetkateteret plasseres i hjertet via en femoralvene ved hjelp av et føringssystem. c) Når kateteret er inne i hjertet, utføres hele prosedyren fra kontrollrommet. Kateteret kan beveges i alle retninger ved hjelp av styrespak og datamus. Kateterplasseringen kontrolleres via gjennomlysningsskjerm og et tredimensjonalt elektroanatomisk kartleggingsystem. d) Rekonstruksjon av venstre ventrikkel med et tredimensjonalt elektroanatomisk kartleggingsystem. Pilene er virtuelle vektorer. Med grønn pil angis den ønskede retning på magnetfeltet. Gul pil vil følge etter grønn pil og angi den reelle retning på magnetfeltet til enhver tid (se også figur 2). Etter denne prosessen vil magnetkateteret (grønt punkt mellom de to pilene) plassere seg i det ønskede området

Magnetkateteret plasseres i hjertet via en femoralvene ved hjelp av et føringssystem (fig 1b). Nøyaktig navigering av kateteret oppnås ved å endre retning på magnetfeltet. Kateteret kan dermed orienteres trinnvis med en nøyaktighet på inntil $1^{\circ}$, forflytning av kateterspissen så presist som ned til $1 \mathrm{~mm}$. Magnetfeltet fjernstyres av datateknologi fra et kontrollrom (fig 1C). Ved å benytte samme vektor på magnetfeltet kan kateteret navigeres tilbake til identisk posisjon i hjertet (1). Navigasjonssystemet er kun fullt integrert med ett tredimensjonalt elektroanatomisk kartleggingssystem (CARTO-RMT, Biosense Webster, USA) (fig 1d, fig 2). 


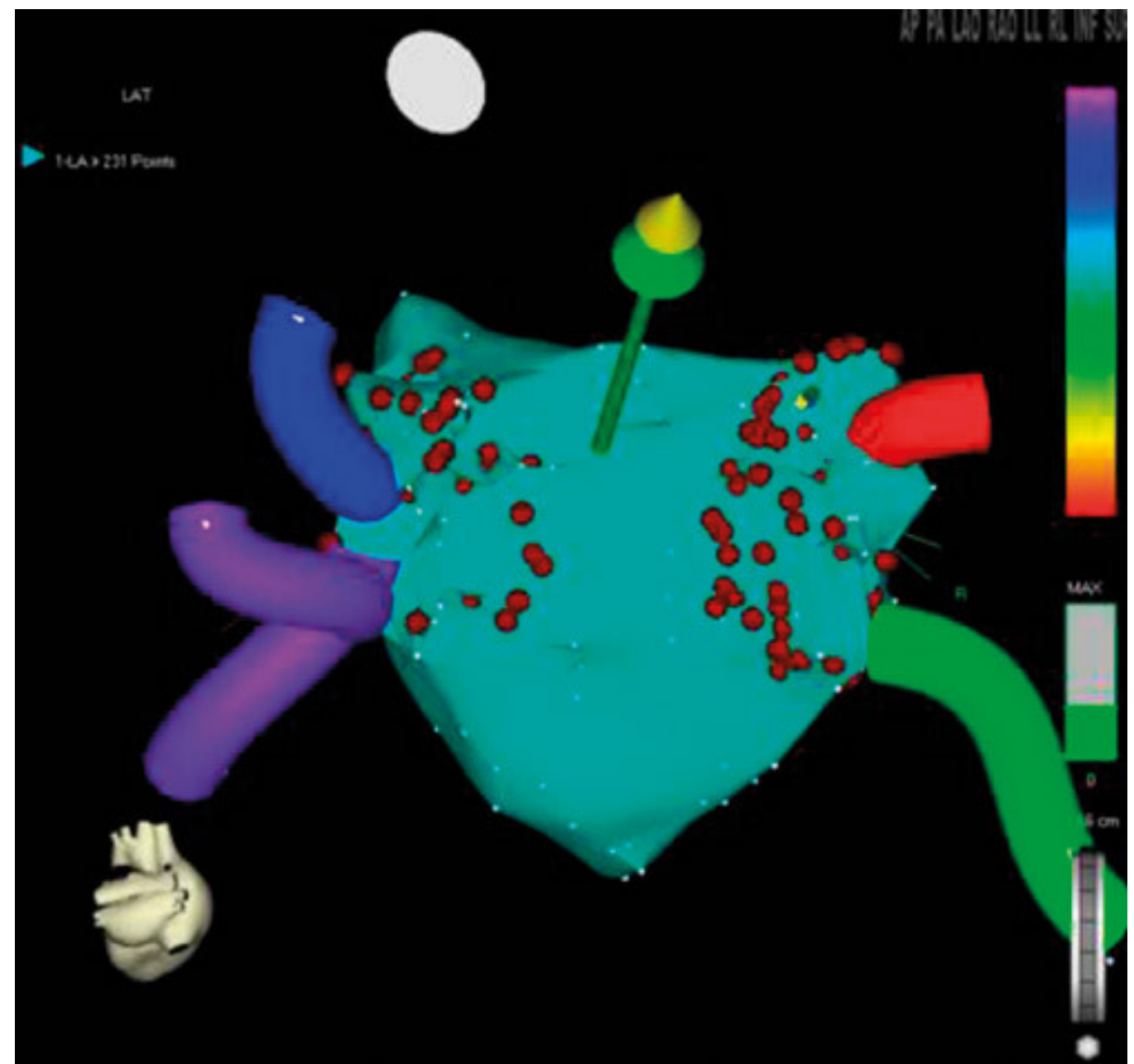

Figur 2 Tredimensjonalt rekonstruert bilde av venstre atrium med lungevener. De hvite punktene angir mekanisk kontakt med atrieveggens innside, som danner basis for rekonstruksjonen. De røde punktene angir ablasjonsområdene rundt lungevenene. Grønn og gul pil (her sammenfallende) viser ønsket og reell retning på magnetfeltet på det tidspunkt bildet er tatt opp (se også figur 1)

Prosedyrene starter med en standard elektrofysiologisk undersøkelse, der man ved hjelp av flere midlertidige katetre i hjertet får en fremstilling av dets elektriske aktivering ved normal rytme og den aktuelle takyarytmi. Deretter føres det magnetstyrte kateteret inn til målområdet for ablasjonen (므). Hos pasienter med atrieflimmer utføres lungeveneisolasjon. Ablasjonen medfører at arytmitriggende elektriske impulser fra lungevenene ikke kan nå venstre forkammer (3). Hos noen pasienter utføres i tillegg ablasjon av komplekse fraksjonerte atrieelektrogrammer. Disse elektrogrammene representerer områder i forkammeret med uheldig endret ledningsevne (4.). Ablasjonsenergien leveres fra en standard generator.

\section{Klinisk bruk av magnetisk navigasjon}

Etter at anvendeligheten av magnetisk kateternavigasjon hos mennesker med hjerterytmeforstyrrelser var demonstrert i 2003 (1), ble de første kliniske studier med pasienter med supraventrikulære takykardier publisert $(\underline{2}, 5, \underline{6})$. Metoden er også innført i

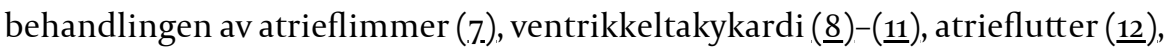
atrietakykardi (13) samt medfødte hjertefeil (1․) og karanomalier $(\underline{15}, \underline{16})$, der standard manuelle metoder ikke gjør det mulig å føre katetrene til arytmisubstratet.

De fleste publiserte arbeider omfatter et begrenset antall pasienter, er gjort for å vurdere metodens anvendelighet og er gjerne basert på kasuistiske meddelelser og observasjonsstudier. Hovedårsaken til dette er at metoden har vært under rask utvikling, 
særlig gjelder det forbedring av kateterteknologien. I en randomisert studie oppnådde man ikke måltallet for pasienter pga. manglende rekruttering (17.).

ATRIEFLIMMER

Atrieflimmer er blitt den tallmessig dominerende indikasjon for kateterablasjon. De fleste med medikamentresistent atrieflimmer har mye plager og redusert livskvalitet. Ablasjonsprosedyren for atrieflimmer er kompleks, teknisk utfordrende og tidkrevende (fig 2). Internasjonale retningslinjer angir at ablasjonsbehandling kan være effektivt ved

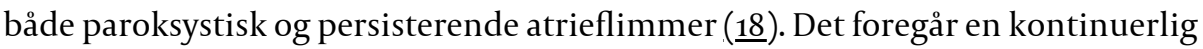
metodeutvikling. Nye og mer omfattende ablasjonsprosedyrer med isolasjon av større områder i venstre atrium har redusert residivfrekvensen ved paroksystisk og persisterende

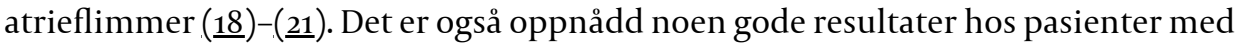
permanent atrieflimmer, hjertesvikt og organisk hjertesykdom $(\underline{22}, \underline{23})$.

Den første studien om magnetstyrt ablasjon ble publisert i 2006 (7.). Den viste at prosedyren var gjennomførbar og trygg - det var ikke noen prosedyrerelaterte komplikasjoner. En studie har vist at atrieflimmerablasjon med magnetisk navigasjon halverte gjennomlysningstiden (fra 17,5 minutter til 8,9 minutter) og reduserte prosedyretiden, selv om en del av lungeveneisolasjonen måtte utføres med hjelp av konvensjonelt kateter (204). I en nyere studie ble det påvist liknende resultater gjennomlysningstiden gikk ned fra 58,6 minutter til 19,5 minutter og prosedyretiden fra 279 minutter til 209 minutter (25). Kliniske resultater ved langtidsoppfølging etter ett år viste at 16 av 20 pasienter behandlet med magnetisk navigasjon var i sinusrytme, mot 15 av 20 behandlet med manuell metode. Magnetisk navigasjon gir også en mulighet til å utføre ablasjon av atrieflimmer ved retrograd tilgang via aorta hos pasienter der det er

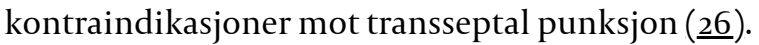

\section{VENTRIKKELTAKYKARDI}

Kateterablasjon av ventrikkeltakykardi fra høyre eller venstre ventrikkel hos pasienter med strukturelt normalt hjerte er en klasse I-indikasjon i retningslinjene fra American College of Cardiology, American Heart Association og European Society of Cardiology (ㄱ․).

Takykardi som har utgangspunkt i høyre eller venstre ventrikkels utløp er den vanligste form for ventrikkeltakykardi hos individer uten kjent organisk hjertesykdom. Enkelte kan ha uttalte plager, med palpitasjoner og synkoper. Medikamenter har ofte liten effekt og kan gi betydelige bivirkninger. Kateterablasjon anbefales derfor ved symptomgivende takykardi. Det angis primærsuksess under prosedyren hos over $90 \%$ av pasientene (27.). I spesielle områder, som nær koronararterienes ostier og epikard, er det vanskeligere og farligere å gjøre ablasjon. I rapporter som omhandler bruk av magnetisk navigasjon ved kateterablasjon av ventrikkeltakykardi angis at teknikken er gjennomførbar, med mulig bedre effekt enn manuelt styrt ablasjon $(\underline{8}, .9, \underline{28})-(3 \underline{0})$. Flere studier har vist at ablasjon av takykardi som oppstår ved koronararterienes ostier og epikardialt med magnetisk navigasjon var trygt og ikke spesielt komplisert (10, $\underline{11})$. Særlig hos yngre individer med ellers normalt hjerte vil kurativ ablasjonsbehandling være å foretrekke fremfor medikamentell antiarytmisk behandling og implantasjon av kardioverterdefibrillator begge er etter vår mening å betrakte som symptomatiske og usikre behandlingsalternativer.

Magnetisk ablasjon har vært utført i begrenset omfang hos pasienter med arrbetinget ventrikkeltakykardi etter hjerteinfarkt og ved myokardsykdom der pasienten i dag stort sett tilbys behandling med implanterbar kardioverterdefibrillator. Dette er en pasientgruppe med kompleks hjertesykdom, ofte med flere takykardimorfologier der det trengs omfattende ablasjonsprosedyrer. I en observasjonsstudie av magnetstyrt navigasjon hos 24 pasienter, hvorav 19 hadde implantert kardioverterdefibrillator, fant man at presisjonen i å påvise arrvev og identifisere arytmisubstratet var høyere enn ved manuell metode. Etter behandlingen var 20 av 24 pasienter residivfrie i en observasjonsperiode på inntil 12 måneder (므). 
Det er nylig publisert en studie med fire pasienter som selv under optimal behandling med antiarytmika og kardioverterdefibrillator hadde hyppige takykardianfall (elektrisk storm). Disse ble vellykket ablasjonsbehandlet via magnetisk navigasjon med et nytt kjølekateter (31). For dem med organisk hjertesykdom viser en studie effekt på ventrikkeltakykardi hos ti av 17 pasienter der det ble brukt en kateterelektrode på $8 \mathrm{~mm}$, mot effekt hos seks av 27 ved bruk av en kateterelektrode på $4 \mathrm{~mm}(\mathrm{p}=\mathrm{o}, 014)$ (30) .

Kurativ ablasjonsbehandling av pasienter med ventrikkeltakykardi er en stor utfordring. Behandlingen utføres i dag sjelden hos disse, og antall pasienter på landsbasis er uavklart. Magnetstyrt ablasjonsbehandling kan være et alternativ til symptomatisk medikamentell behandling, som ofte har begrenset effekt.

ANDRE ARYTMIER

I et materiale som omfattet 42 pasienter med supraventrikulær takykardi, ble alle vellykket behandlet med magnetstyrt ablasjonsteknikk - uten residiv og uten komplikasjoner i oppfølgingsperioden på fire måneder (므). I en multisenterstudie med en liknende pasientgruppe var det en umiddelbar suksessrate på $91 \%$ ved magnetisk navigasjon, mot $87 \%$ ved manuell ( $\mathrm{p}>0,05)$, og det var kortere gjennomlysningstid ved magnetisk navigasjon (17.). Komplikasjonsraten i denne studien var 5,4\% ved magnetisk styrt ablasjon, mot 6,7\% ved manuelt styrt ( $\mathrm{p}>0,05$ I andre studier har det vært liknende observasjoner når det gjelder pasienter med atrietakykardi $(13,29)$.

Resultatene ved behandling av atrieflutter er varierende. I ett materiale var det en suksessrate på $96 \%$ ( 24 av 25 pasienter), mens det i en annen gruppe bare var suksess hos 12 av 22 pasienter (55\%) - med for øvrig sammenliknbare teknikker $(\underline{12}, \underline{29}$.). Ved bruk av manuelt styrte kjølekatetre økte suksessraten (29.).

MEDFØDTE HJERTEFEIL OG KARMALFORMASJONER

Hos pasienter med kompliserte medfødte hjertefeil og spesielle karmalformasjoner (14.)(16) kan magnetstyrt kateterføring være eneste mulighet for å nå målområdet. Det er fordi manuelt styrte katetre er mindre fleksible. De som er operert for transposisjon, risikerer alvorlige takykardier og plutselig død og representerer en særlig utfordring når det oppstår arytmiproblemer.

\section{Komplikasjoner}

Vurdering av alle aspekter ved behandlingen og sikkerheten står sentralt ved innføring av nye terapeutiske prosedyrer. Ut fra samledata fra tidligere undersøkelser hvor man har benyttet manuelle metoder, er det ved behandling av atrieflimmer prosedyrerelaterte komplikasjoner hos inntil $6 \%$ av pasientpopulasjonen (묘). Komplikasjonene inkluderer lungevenestenose, tromboembolisme og fistel mellom venstre forkammer og spiserør. I et tidligere publisert arbeid fant vi at det med konvensjonelle metoder var komplikasjoner i tre av 86 prosedyrer ( $3,5 \%)$, hvorav ett tilfelle av lungevenestenose, ett av tamponade som krevde perikardtapping og ett av oksipital embolisme med synsfeltsutfall (3).

I de fleste arbeider rapporteres det at magnetisk navigasjon blir utført uten komplikasjoner $(\underline{2}, 5,-7, \underline{8}, \underline{12}, \underline{29}, 3 \underline{2})$. I en sammenliknende undersøkelse oppsto det tamponade hos to pasienter $(2,2 \%)$ som ble behandlet med manuell kateternavigasjon, mens det ikke var noen komplikasjoner forbundet med magnetisk navigasjon (33).

\section{Metodens utvikling}

Hensikten med innføring av ny teknologi er å videreutvikle eksisterende behandlingsmetoder. Når det gjelder de aktuelle pasientgrupper, ønsker man å oppnå sikrere og mer skånsom manøvrering av katetrene, samtidig som man vil korte ned 
prosedyretiden og minske strålebelastningen. I et materiale hvor samtlige prosedyrer ble utført av én person, fant man at prosedyretiden holdt seg stabil etter at de første 12 pasientene var behandlet (7.).

Siden vi foreløpig har begrenset erfaring med metoden, har vi ikke kunnet gjøre den totale prosedyretiden kortere enn tiden ved manuell ablasjon. Dette er også vist $i$ andre studier. Det skyldes først og fremst en noe mer tidkrevende prosess ved oppstart av systemene, innføringen av magnetkateteret og den elektroanatomiske kartleggingen. Men for erfarne operatører kreves det ikke lang opplæring for å beherske utstyr og prosedyrer. I egne upubliserte data har vi funnet at ablasjons- og prosedyretider og gjennomlysningstider for pasienter med atrieflimmer er sammenliknbare med det man finner i tilsvarende pasientmaterialer $(\mathbf{2}, 7.7)-(9,19)$. Vi har hittil ikke kunnet applisere kjølevæske under ablasjon, noe som er vanlig ved manuelle prosedyrer. Katetrene er under utvikling. Slike vil redusere muligheten for koageldanning på elektroden og dermed føre til økt pasientsikkerhet ved ablasjon i det systemiske kretsløp.

\section{Fordeler og begrensninger}

Fordelen ved magnetstyrt navigasjon er at kateteret er mykere og mer fleksibelt enn manuelt styrte katetre. Dette gjør at det er liten risiko for intravaskulære komplikasjoner, det blir mindre trykk mot endokard og dermed mindre fare for hjerteperforasjon og mekanisk fremkalte hjerterytmeforstyrrelser som vanskeliggjør den elektroanatomiske kartleggingen $(\underline{28}, 3 \underline{0})$. Samtidig kan et lavt katetertrykk mot endokard medføre behov for lengre applikasjonstid. Siden kateteret er i et statisk magnetisk felt, får det en mer stabil posisjon under hjertekontraksjonen enn et manuelt styrt kateter og holder en mer konstant temperatur under ablasjonen (34).

Kontinuerlig utvikling av magnetkatetre har ført til forenkling av ablasjonsprosedyren (5). Ved at manøvreringen foregår via en styrestikke i et kontrollrom, er strålebelastningen og den fysiske belastningen langt mindre for operatøren. Publiserte arbeider viser at strålebelastningen er redusert med inntil to tredeler sammenliknet med tidligere metoder (31). Dette er av særlig betydning ved en prosedyrevarighet på 6-8 timer, som ikke er uvanlig ved ablasjon av atrieflimmer og ventrikkeltakykardi. En begrensning ved utstyret har vært manglende mulighet til å applisere kjølevæske gjennom magnetkateteret. Slike katetre er nylig tatt i bruk. Kjølevæske vil sannsynligvis gi dypere vevslesjoner, mulig kortere prosedyretid og høyere behandlingssuksess (31).

Siden manuell kateterablasjon av supraventrikulær takykardi er relativt enklere, vil anvendelse av magnetisk navigasjon være mindre aktuelt ved rutineprosedyrer. For langvarige og kompliserte tilstander som atrieflimmer og ventrikkeltakykardi og hos pasienter med strukturelle anomalier kan metoden innebære store fordeler.

Radiofrekvensablasjon av hjerterytmeforstyrrelser er nå etablert ved alle fem regionsykehus i Norge. Det magnetiske navigasjonsutstyret er foreløpig bare i drift ved Haukeland universitetssykehus. Kostnadene ved å bygge et komplett magnetstyrt laboratorium for ablasjonsbehandling av hjertearytmi er i størrelsesorden 30 millioner kroner. Når grunnlagsinvesteringen er gjort, vil utgiftene til forbruksmateriell være på samme nivå som ved dagens konvensjonelle metoder. Det er av vesentlig betydning at også norske miljøer gis muligheten til å teste ut ny teknologi i et ekspanderende fagområde - og helst i kontrollerte studier.

$\emptyset$ Øonomisk støtte: Våre erfaringer skriver seg fra bruk av et etablert magnetlaboratorium, som er støttet med gavemidler fra Trond Mohn og Norges forskningsråd (gaveforsterkningsordningen).

\section{Oppgitte interessekonflikter:}


Peter Schuster fikk Biosense Websters Nordic invasive electrophysiology-stipend i 2007. De andre forfatterne har ingen oppgitte interessekonflikter.

\section{Tabell}

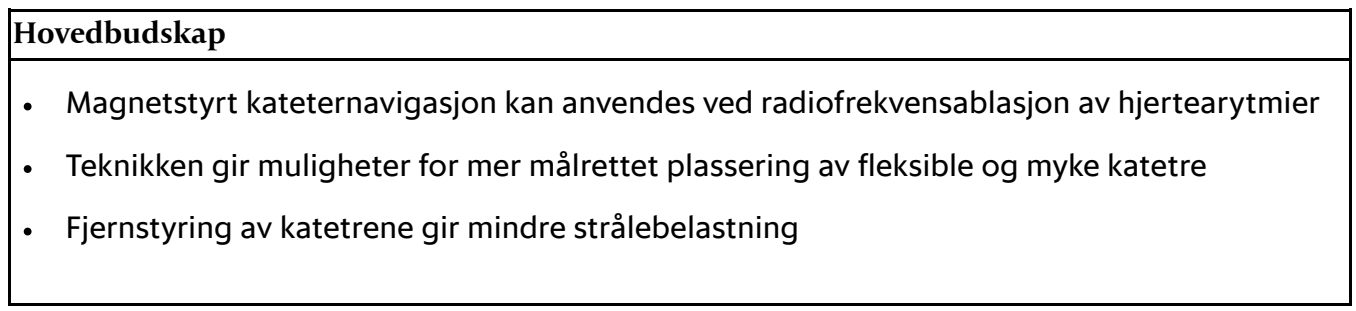

\section{LITTERATUR}

1. Faddis MN, Chen J, Osborn J et al. Magnetic guidance system for cardiac electrophysiology: a prospective trial of safety and efficacy in humans. J Am Coll Cardiol 2003; 42:1952-8. [PubMed] [CrossRef]

2. Ernst S, Ouyang F, Linder $C$ et al. Initial experience with remote catheter ablation using a novel magnetic navigation system. Magnetic remote catheter ablation. Circulation 2004; 109:1472-5. [PubMed] [CrossRef]

3. Hoff PI, Chen J, Erga KS et al. Kurativ behandling av paroksysmal atrieflimmer med radiofrekvensablasjon. Tidsskr Nor Lægeforen 2004; 124: 625-8. [PubMed]

4. Nademanee K, McKenzie J, Kosar E et al. A new approach for catheter ablation of atrial fibrillation: mapping of the electrophysiologic substrate. J Am Coll Cardiol 2004; 43: 2044-53. [PubMed] [CrossRef]

5. Chun JK, Ernst S, Matthews S et al. Remote-controlled catheter ablation of accessory pathways: results from the magnetic laboratory. Eur Heart J 2007; 28: 190-5. [PubMed] [CrossRef]

6. Thornton AS, Rivero-Ayerza M, Knops P et al. Magnetic navigation in left-sided AV reentrant tachycardias: preliminary results of a retrograde approach. J Cardiovasc Electrophysiol 2007; 18: 46772. [PubMed] [CrossRef]

7. Pappone C, Vicedomini G, Manguso F et al. Robotic magnetic navigation for atrial fibrillation. J Am Coll Cardiol 2006; 47: 1390-400. [PubMed] [CrossRef]

8. Thornton AS, Jordaens LJ. Remote magnetic navigation for mapping and ablating right ventricular outflow tract tachycardia. Heart Rhythm 2006; 3: 691-6. [PubMed] [CrossRef]

9. Thornton AS, Res J, Mekel JM et al. Use of advanced mapping and remote magnetic navigation to ablate left ventricular fascicular tachycardia. Pacing Clin Electrophysiol 2006; 29: 685-8. [PubMed] [CrossRef]

10. Aryana A, d'Avila A, Heist K et al. Remote magnetic navigation to guide endocardial and epicardial catheter mapping of scar-related ventricular tachycardia. Circulation 2007; 115: 1191-200. [PubMed]

11. Burkhardt JD, Saliba WI, Schweikert RA et al. Remote magnetic navigation to map and ablate left coronary cusp ventricular tachycardia. J Cardiovasc Electrophysiol 2006; 17: 1142-4. [PubMed] [CrossRef]

12. Arya A, Kottkamp H, Piorkowski C et al. Initial clinical experience with a remote magnetic catheter navigation system for ablation of cavotricuspid isthmus-dependent right atrial flutter. Pacing Clin Electrophysiol 2008; 31: 597-603. [PubMed] [CrossRef]

13. Mehta R, Hart DT, Nagra BS et al. Successful ablation of focal left atrial tachycardia using Stereotaxis Niobe remote magnetic navigation system. Europace 2008; 10: 280-3. [PubMed] [CrossRef]

14. Wu J, Pflaumer A, Deisenhofer I et al. Mapping of intraatrial reentrant tachycardias by remote magnetic navigation in patients with d-transposition of the great arteries after mustard or senning procedure. J Cardiovasc Electrophysiol 2008; 19: 1153-9. [PubMed] [CrossRef]

15. Ernst S, Chun JK, Koektuerk B et al. Magnetic navigation and catheter ablation of right atrial ectopic tachycardia in the presence of a hemi-azygos continuation: a magnetic navigation case using 3D electroanatomical mapping. J Cardiovasc Electrophysiol 2009; 20: 99-102. [PubMed] [CrossRef] 
16. Kim AM, Badhwar N, Lee RJ. Remote navigation guided ablation of incessant atrial tachycardia in a patient with restricted venous access. J Cardiovasc Electrophysiol 2009; 20:1061-4. [PubMed] [CrossRef]

17. Wood MA, Orlov M, Ramaswamy Ket al. Remote magnetic versus manual catheter navigation for ablation of supraventricular tachycardias: a randomized, multicenter trial. Stereotaxis Heart Study Investigators. Pacing Clin Electrophysiol 2008; 31: 1313-21. [PubMed] [CrossRef]

18. Fuster V, Rydén LE, Cannom DS et al. ACC/AHA/ESC 2006 guidelines for the management of patients with atrial fibrillation: full text: a report of the American College of Cardiology/American Heart Association Task Force on practice guidelines and the European Society of Cardiology Committee for Practice Guidelines (Writing Committee to Revise the 2001 guidelines for the management of patients with atrial fibrillation). Europace 2006; 8: 651-745. [PubMed] [CrossRef]

19. Oral H, Chugh A, Good E et al. A tailored approach to catheter ablation of paroxysmal atrial fibrillation. Circulation 2006; 113: 1824-31. [PubMed] [CrossRef]

20. Solheim E, Hoff PI, Off M et al. Significance of late recurrence of atrial fibrillation during longterm follow-up after pulmonary vein isolation. Pacing Clin Electrophysiol 2007; 3: S108-11. [PubMed] [CrossRef]

21. Chen J, Off M, Hoff PI et al. Treatment of atrial fibrillation by silencing electrical activity in the posterior inter-pulmonary vein atrium. Europace 2008; 10: 265-72. [PubMed] [CrossRef]

22. Hsu LF, Jaïs P, Sanders P et al. Catheter ablation for atrial fibrillation in congestive heart failure. N Engl J Med 2004; 351: 2373-83. [PubMed] [CrossRef]

23. Khan MN, Jaïs P, Cummings J et al. Pulmonary-vein isolation for atrial fibrillation in patients with heart failure. N Engl J Med 2008; 359: 1778-85. [PubMed] [CrossRef]

24. Di Biase L, Fahmy TS, Patel D et al. Remote magnetic navigation: human experience in pulmonary vein ablation. J Am Coll Cardiol 2007; 50: 868-74. [PubMed] [CrossRef]

25. Katsiyiannis WT, Melby DP, Matelski JL, et al. Feasibility and safety of remote-controlled magnetic navigation for ablation of atrial fibrillation. Am J Cardiol 2008; 102: 1674-6. [PubMed] [CrossRef]

26. Miyazaki S, Nault I, Haïssaguerre M et al. Atrial fibrillation ablation by aortic retrograde approach using a magnetic navigation system. J Cardiovasc Electrophysiol 2010; 21: 455-7. [PubMed] [CrossRef]

27. Zipes DP, Camm AJ, Borggrefe M et al. ACC/AHA/ESC 2006 guidelines for management of patients with ventricular arrhythmias and the prevention of sudden cardiac death: a report of the American College of Cardiology/American Heart Association Task Force and the European Society of Cardiology Committee for Practice Guidelines (Writing Committee to Develop Guidelines for Management of Patients With Ventricular Arrhythmias and the Prevention of Sudden Cardiac Death). J Am Coll Cardiol 2006; 48: e247-346. [PubMed] [CrossRef]

28. Konstantinidou M, Wissner E, Koektuerk B et al. Remote magnetic navigation and catheter ablation in the right ventricular outflow tract - a simplified approach. Europace 2009; 11 (suppl 6): Abstrakt 349 .

29. Latcu DG, Richard P, Zargane N et al. Robotic magnetic navigation for ablation of human arrhythmias. Arch Cardiovasc Dis 2009; 102: 419-25. [PubMed] [CrossRef]

30. Di Biase L, Burkhardt JD, Lakkireddy D et al. Mapping and ablation of ventricular arrhythmias with magnetic navigation: comparison between 4-and 8-mm catheter tips. J Interv Card Electrophysiol 2009; 26: 133-7. [PubMed] [CrossRef]

31. Haghjoo M, Hindricks G, Bode K et al. Initial clinical experience with the new irrigated tip magnetic catheter for ablation of scar-related sustained ventricular tachycardia: a small case series. J Cardiovasc Electrophysiol 2009; 20: 935-9. [PubMed] [CrossRef]

32. Pflaumer A, Hessling G, Luik A et al. Remote magnetic catheter mapping and ablation of permanent junctional reciprocating tachycardia in a seven-year-old child. J Cardiovasc Electrophysiol 2007; 18: 882-5. [PubMed] [CrossRef]

33. Kim AM, Turakhia M, Lu J et al. Impact of remote magnetic catheter navigation on ablation fluoroscopy and procedure time. Pacing Clin Electrophysiol 2008; 31:1399-404. [PubMed] [CrossRef]

34. Davis DR, Tang AS, Gollob MH et al. Remote magnetic navigation-assisted catheter ablation enhances catheter stability and ablation success with lower catheter temperatures. Pacing Clin Electrophysiol 2008; 31: 893-8. [PubMed] [CrossRef]

Publisert: 12. august 2010. Tidsskr Nor Legeforen. DOI: 10.4045/tidsskr.09.0249

Manuskriptet ble mottatt 17.2. 2009 og godkjent 29.4. 2010. Medisinsk redaktør Trine B. Haugen. (C) Tidsskrift for Den norske legeforening 2023. Lastet ned fra tidsskriftet.no 26. april 2023. 